\title{
Thrown Together: Incorporating Place and Sustainability into Early Literacy Education
}

\author{
Catarina Schmidt ${ }^{1}$ (D)
}

Published online: 21 June 2017

(C) The Author(s) 2017. This article is an open access publication

\begin{abstract}
The development of language and literacy abilities of young multilingual children is important to their future educational engagement and success in school. In this study, the value of taking account of place and sustainability in early literacy education is considered. This research provides ideas for practice-based research on early literacy in multilingual and community-based contexts. In a case study with a Grade 1 classroom in Sweden, the researcher and the teacher implemented various literacy activities to bring children's own powerful knowledge about place into the classroom. This enabled young children to actively engage with language and literacy in authentic and meaningful ways. Early childhood teachers need to be aware of the importance of incorporating ideas about place and sustainability into early literacy education in order to avoid deficit discourses and instead build participatory practices and support democratic values. Bringing literacy and place together in education can address what is perhaps one of the most crucial questions of sustainability, namely how people within a community can live together while having different values, beliefs and dreams.
\end{abstract}

Keywords Education for sustainable development (ESD) - Childhood · Early literacy education · Place-based pedagogy $\cdot$ Authentic literacy activities

Résumé Le développement des habiletés des jeunes enfants multilingues en matière de langage et de littératie est important pour leur engagement éducationnel et leur réussite scolaire futurs. Cette étude porte sur l'importance de prendre en compte le lieu et le développement durable dans l'éducation des jeunes enfants à la littératie. Cette recherche donne des idées pour des études axées sur la pratique en éducation des jeunes enfants à la littératie, en contextes multilingues et

Catarina Schmidt

catarina.schmidt@gu.se

1 Gothenburg University, Läroverksgatan 15, 40530 Göteborg, Sweden 
communautaires. Dans une étude de cas faite en Suède dans une classe delère année, le chercheur et l'enseignant ont mis en place diverses activités de littératie pour introduire dans la classe les puissantes connaissances des enfants sur le lieu. Ceci a permis aux jeunes enfants de s'engager activement en langage et littératie, de manière authentique et significative. Il faut que les enseignants du préscolaire soient conscients de l'importance d'introduire des idées sur le lieu et la durabilité dans l'éducation des jeunes enfants à la littératie afin d'éviter les discours déficitaires et de plutôt construire des pratiques participatives et soutenir les valeurs démocratiques. Joindre en éducation, lieu et littératie peut aborder peut-être une des questions les plus cruciales du développement durable, à savoir comment, dans une communauté, les gens peuvent vivre ensemble tout en ayant des valeurs, des croyances et des rêves différents.

Resumen El desarrollo de las habilidades lingüísticas y la competencia lectora/ expresión escrita de los alumnos multilingües es importante para su futuro éxito en la escuela. En este estudio consideramos el valor que tiene el contexto educativo y la sostenibilidad en las edades tempranas de la escolarización. Esta investigación proporciona ideas prácticas acerca de la competencia lectora y la expresión escrita en contextos multilingües y comunitarios. Específicamente, se muestra un estudio de caso en un aula de primer grado de primaria en Suecia, donde el investigador y el maestro implementaron varias actividades de comprensión lectora/expresión escrita para incentivar el conocimiento de los niños sobre el contexto escolar. Esto permitió a los niños pequeños participar activamente en la apropiación de las destrezas, de manera auténtica y significativa. Los maestros de la escuela primaria deben ser conscientes de la importancia de incorporar ideas sobre el medio y la sostenibilidad en la educación temprana para evitar discursos no auténticos, en lugar de construir prácticas participativas y apoyar el desarrollo de valores democráticos. Tratar de llevar de la mano la lectura y escritura con el medio en el proceso educativo puede, quizás, ser una de las cuestiones más cruciales de la sostenibilidad, es decir, cómo las personas dentro de una comunidad pueden vivir juntas a pesar de que tengan diferentes valores, creencias y sueños.

\section{Introduction}

Learning about being a citizen and contributing to the community can begin in early childhood classrooms. In particular, education for sustainable development can cover a wide range of seemingly complex questions that can be incorporated into the practices of early childhood education (Hägglund and Samuelsson 2009; UNESCO 2005). Early childhood teachers can introduce ideas concerned with social, economic and environmental sustainability into their practices that take account of children's own communities. Through such practices, children learn, from an early age, about citizenship and about their place in their world through understandings about their world in which they live. In this case study in a Grade 1 classroom in Sweden, the researcher and the teacher introduced various literacy 
activities to bring children's own powerful knowledge about place into the classroom

In the Swedish national curriculum Lgr 11 (National Agency of Education 2011), it is stated that "by providing a wealth of opportunities for discussion, reading and writing, all pupils should be able to develop their ability to communicate and thus enhance confidence in their own language abilities" (p. 11). Drawing on Lgr 11, education should promote learning based on the student's background, earlier experiences, language and knowledge. The concept of sustainability can be introduced within a range of curriculum areas. Through education, and hence through the teaching and learning of all subjects, students should, according to Lgr 11 , be able to "form a personal position with respect to overarching and global environmental issues" (p. 12).

In 2016, new knowledge requirements were implemented regarding decoding and reading comprehension, which at the present time have an impact on both the preschool class and Year 1 in terms of increased demands regarding basic and functional literacy. At the same time, children's creative activities, such as play and esthetic forms of expressions, are seen as essential components in the early school years. When also adding aspects of sustainability, the complexity for contemporary early childhood education in Sweden is increasing.

This paper examines how children can become meaningfully engaged in, and aware of, sustainability, drawing on places and circumstances from their everyday lives while they at the same time and through these processes develop communicative literacy abilities. Such arrangements have been researched very little in Swedish contexts. Sommerville and Williams (2015) similarly point out that there is little empirical research to provide the necessary foundation for early childhood education in relation to sustainability.

\section{Place-Based Education and Literacy Learning}

As human beings, we share places where we continuously negotiate ways of being together. A certain place means different things for different people, and likewise a place or a community is never a stable thing. Nevertheless, all places carry stories and memories. When, and if, we connect to a certain place, we can do that in terms of remembering, listening, exploring and learning, and these actions are, as Apple (2010) claims, always relational. Researching and learning about a place also mean sensing a place, as accentuated by Sommerville (2011a, p. 13) in the following:

In researching place, we give space to what our senses tell us about the places in which we find ourselves. We ask ourselves what we can see, hear, feel, sense and touch in each of our places. At the same time the research requires the hard work of finding new ways to conceptualise place that enable us to break with those preconceptions that have separated us off from place and divested us of responsibility toward place. 
To be part of a place might hence mean to hear, feel, sense and touch that place. Being part of a place poses, as Massey (2005) puts it, "the question of our throwntogetherness" (p. 151). Teachers and children are "thrown together" at certain places and spaces within and nearby schools. Massey highlights the practicing of place where she states, "negotiating is forced upon us" (p. 154). What then might negotiation in contemporary education mean?

Drawing on major educational theorists that include Friedrich Froebel, Maria Montessori and John Dewey, Nussbaum (2010) articulates how education is not about "passive assimilation of facts and cultural traditions, but about challenging the mind to become active, competent and thoughtfully critical in a complex world" (p. 18). One way to encourage children to be thoughtfully critical in educational settings is to give them access to situations where they can question, argue, speculate, justify and negotiate about things that are perhaps understood differently by different people. Vasquez (2001) imagines "negotiation and contestation at the centre" of such critical conversations, rather than "a more familiar process of discovering the best way" and she further underlines that the "ongoing process of adjusting and re-constructing" should be in focus "rather than the accumulating of information" (p. 54).

Practicing and sensing place might mean powerful ways of linking sustainable issues to children's everyday world and learning. Sommerville (2011b) reports on an integrated educational program of primary school children and teachers in Australia, involving local wetlands. She describes the children's bodily engagement and how they were listening to, photographing and audio-recording frogs. At the same time, memories, stories and knowledge of this particular area of wetland were brought into the classrooms by the involvement of local indigenous elders. The children were then invited to represent their understanding and learning using different forms of expression. In one of the productions, the children composed and performed their own music, and made up entirely of frog calls.

Additionally, and in this case drawing on Comber (2016), the practice of place, through processes of exploration and negotiation, might mean opportunities to get away from deficit discourses, the latter being defined by her as explaining away "a lack of learning by referring to children's family background" (p. xvi). Comber argues that a place that is defined by poverty does not need to limit in any way children's literacy learning. Avoiding deficit discourses, and instead turning them upside down, might mean that children's semiotic, linguistic and literacy resources are recognized and valued. Further, it might mean that teachers creatively design education in ways that provide opportunities for inquiry and imagination. Such place-based pedagogy might result in education drawing on both familiar and more unknown conditions in different places, and that this is then linked to certain knowledge requirements in the curriculum as well as the surrounding world. Thinking and asking authentic questions about places in the local neighborhood can metaphorically be compared to reading the world as a text, linking local issues to global ones (Freire 1970).

Luke and Freebody (1997) describe in the Four Resources Model how effective literacy invites and allows students to take part in practices supporting not only coding, functional use and meaning-making of texts, but also critical analysis of 
texts. The concept of text includes spoken, visual, audial and written texts as well as the multimodal understanding of communication and knowledge (Danielsson and Selander 2016; Kress 1997).

Breaking the code of texts relates to understanding the ways in which texts are structured, and in relation to script, this includes alphabet, sounds, spelling and other conventions that constitute the more technical side of mastering a language. It is necessary to recognize, distinguish and manipulate the basic sound structures of a language, such as syllables and phonemes, in order to "crack the code" of alphabetical script (Lourenco and Andrade 2013). At the same time, learners of literacy need to get involved in practices that also support the functional use and meaning-making of texts. Functional use relates to strategies for understanding and creating different types of texts with specific purposes, while making meaning through texts also involves the incorporation of one's own lifeworld and experiences into these processes. Further, Luke and Freebody (1997) stress how possibilities for critical analysis and transformations of texts are crucial, since texts represent particular points of view while silencing others.

In a similarly balanced approach, Cummins (2001) highlighted that a focus on meaning, a focus on language and a focus on use are crucial in scaffolding children's language and learning. The focus on meaning captures the need to make content comprehensible. In parallel and dependent processes, children also need to scaffold to develop awareness of language, such as language sounds and how words can be changed, and using language. The three focuses of meaning, language and use are interdependent, just like the practices in the Four Resources Model (Luke and Freebody 1997).

At the core of Cummin's (2001) framework is the interpersonal space, where maximum cognitive engagement and maximum identity investment are pointed out as crucial for children's motivation and learning. If, for example, a child senses his or her specific background is not valued as "good enough", this will affect the child's willingness to participate and invest his or her own identity, which then will create an obstacle to language use and learning. Maximum cognitive engagement relates to the importance of high expectations and the possibility of widening and adapting repertoires of literacy learning in relation to children's different needs and prerequisites. Learning through a child's strongest language can, for example, contribute in important ways to lowering the cognitive barrier for content knowledge. Conversely, if a child's previous knowledge is considerable, this might mean that the child will be able to use language in more advanced ways.

In summary, and drawing on the models proposed by Cummins (2001), as well as Luke and Freebody (1997), literacy education needs to balance all four practices of coding, functional use, meaning-making and critical analysis of texts in orchestrated and contextual ways, in addition to the three focuses of meaning, language and use. Children need educational support in order to use language and literacy for various reasons and purposes, which includes practicing their freedom of speech and thought, as well as interpreting, critiquing and redesigning both texts and the surrounding world. Comber and Nixon (2004) describe the Four Resources Model as a critical literacy approach with a focus "not only on what 
children read and view, but also on what they design, compose and produce across a wide range of genres, medias and modes" (p. 116). According to these authors, having opportunities to redesign texts opens up possibilities for shaping and reshaping one's world through the use of literacy in a personal process of identity making.

With regard to socially situated practices, language is never independent of the surrounding social world (Gee 1996). Children bring resources into these socially situated practices, for example languages, culture and the mastery of different semiotic systems, which might challenge and/or change existing discourses-or not. One burning issue in this paper is how literacy learning across the curriculum can be linked to issues of sustainability where the children's own surrounding world could be read as a "text" to critically evaluate, question, reread and redesign (Comber and Nixon 2004; Freire 1970).

\section{The Current Study}

In this research, a case study was conducted in a Grade 1 classroom in a linguistically rich area (given the fictional name of "Fairfield"). The case study was conducted over 2 months and through 10-day-long visits to Fairfield School which has approximately 400 students, from the preschool class to Grade 6. It is situated on the outskirts of a medium-sized city in Sweden, within a residential area with housing estates of rental apartments, built during the end of the 1960s and the beginning of the 1970s. The neighborhood has just over 30 apartment blocks and includes shops and various community services. The 21 seven-year-old children in Grade 1 live in Fairfield and they had attended the preschool class at the same school during the previous year. A majority of them speak a language other than Swedish in their homes.

In this paper, I explore challenges and possibilities for early literacy teaching and learning in relation to education for sustainable development (ESD), and in relation to the children's own resources, experiences and knowledge of Fairfield as a place.

\section{Methodology}

In the autumn of 2016 across 2 months in 10-day-long visits, I observed the teaching in a first-grade class and carried out interviews with the 21 children in the classroom, in small groups of two children. Drawing on the field notes from the participatory observations and the field notes from the child interviews, I implemented two classroom activities in collaboration with the teacher and the children.

While I made observations, I participated in the classroom activities and listened to and talked to the children. I aimed for a reflexive approach, meaning that I sought to understand the children's individual perspectives within contextualized social practices (Hammersley and Atkinson 1989; Whyte 1999). Following and listening to the children during lessons, breaks and lunchtime meals, as well as during the 
interviews, was a learning process for me as a researcher. The group interviews were semi-structured and revolved mainly around what the children wanted to tell me about themselves, their families, their particular interests, their school and their thoughts about all of this. During the group interviews, I wrote down what the children said on my computer, sometimes pausing and asking for help with certain words or to ask whether I had understood them correctly. While I wrote down what they told me, the two children in each interview sat on either side of me and were able to see what I wrote. The interviews were not recorded. Apart from observations and interviews, I also carried out two whole-class activities in cooperation with their teacher, producing two jointly created big books.

The study was conducted in accordance with the general requirements for research ethics in Sweden (Swedish Research Council 2002). The school and the informants have been given fictitious names in order to protect their identities during and after the project. The teacher and students, as well as the parents of the students, were informed about the aim of the study and then asked to give their written consent for participation, which they all provided.

\section{The Research Context: Fairfield}

Living in Fairfield means living in a culturally and linguistically diverse community, where income and educational levels are generally lower than the rest of the society, and where there is a higher degree of unemployment than in other parts of the municipality. Such lower socioeconomic capital in a community such as Fairfield does not mean lower literacy per se, but it does affect teachers' work in such schools in comparison to teachers' work in more affluent schools. At the same time, exceptions may also be found, for example high educational levels for some families. Whatever the community circumstances, it is of importance to no engage in deficit discourses, a principle that is a challenge for education everywhere.

Living in Fairfield also means living in an area with an accessible and wellfunctioning community service. At the same time, Fairfield has on some occasions been the target of car fires and vandalism, reported in the local newspaper and the TV news. Such activities are countered by positive actions from local volunteers working within various associations and networks, and in close cooperation with the police and staff members from, among other places, the leisure center for adolescents. However, these experiences, in addition to many others of both a positive and less positive character, affect the image of a place like Fairfield.

Although Fairfield School has a long tradition of multilingual students, deficit discourses about the community may still occur. The teaching staff consists of firstlanguage teachers, as well as the teachers working at the leisure center, the preschool class and teachers in Grades 1-6. Lessons in the children's various first languages are carried out once a week and after the school day. The sketches of the community provide possibilities for future development of this work that can be linked to issues of sustainability. 


\section{Findings}

\section{Sketches of Life in Fairfield: Children's Reports}

The children say with confidence that they can sing, dance, produce movies, read, write, draw, jump high and play football and hockey, among other things. They describe how they like to play and mention the many playgrounds in the inner courtyards between the apartment blocks at Fairfield and how they meet friends there and play. One girl, who in the beginning was very shy, and according to her teacher almost always silent in class, suddenly starts to talk a lot when she describes a certain climbing frame, which she calls the "spider climber," and where she likes to play with her siblings. Further, the children describe how they ring on each other's front doors, asking whether a friend wants to play. "In Fairfield the inner courtyards are close to each other" a child says. Another child says: "In Fairfield you have got many friends and therefore you do not feel alone."

The children talk about their families. Some of them have cousins or maybe a grandmother in another country faraway. They do not spontaneously mention their first languages, but when asked they can identify their language without hesitation. In total, the children speak 11 languages: Kurdish, Assyrian, Arabic, Syrian, Finnish, Bosnian, Somalian, Croatian, Pashto, Amarinhan, Tigrinjan and Swedish. All of the children speak Swedish and are in the middle of learning how to write and read in this language. Several of the children read and write in ways that could be described as emergent literacy, meaning that they have developed phonological awareness and also understand the connection between language sounds and the corresponding graphemes. In addition, some of the same children have developed phonological awareness in their first language and sometimes to a higher level. Also, some of the children read and write in their first language.

Many of the children say that they like to learn. A majority express that they like to learn how to read. They mention the municipal library at Fairfield as well as the school library. Also, several of the children state that they like to swim, and talk about the swimming hall in Fairfield. Many children play football, and some of them practice football on a regular basis and take part in various football competitions, some of them carried out on the local football pitch. Other places in Fairfield that are mentioned are various shops, a pizzeria, a mosque and a church. When describing how they like to play, the children also mention the schoolyard. They say that they like to spin on the roundabout, ride on the small bikes that are available, run around, play football, laugh and much more. It is obvious that the schoolyard is an exciting space within Fairfield School.

\section{Literacy Work in the Classroom}

In between the interviews and during my participant observations, the children worked on various literacy exercises, for example practicing how to write the letter "Oo." They listened to their teacher reading aloud and also participated in a joint assembly together with the students from the preschool class, where they sang songs 
together. The children also read together and individually from their reader, The Magic Marble (Wänblad 2011), which is the class textbook. The children also have access to other children's books in the school library, which is close to the classroom.

The textbook is available on two levels, where the easiest level has a typeface that is easier to read and has less text. In 25 freestanding chapters, the students follow the main character Asta and her two friends, Ceasar and Bea. The content covers Asta's everyday life together with a story about a magic marble that she finds. The content does not relate to religion or ethnicity or different language backgrounds. Neither does it relates to places that are to be found within Fairfield.

In summary, the observed teaching during the 10-day-long visits can be described as aiming to give the students access to basic literacy skills. A lesson commonly starts with whole-class teaching where the teacher gives instructions on how to carry out a certain task, and continues with the children completing the rather routine and limited task. If a child finishes a task, additional exercises are given, involving practicing rather isolated literacy skills by filling in gaps, drawing lines and coloring. A pattern that emerges is that one letter at the time is taught regardless of the individual children's pre-knowledge of literacy.

\section{“All That You Have Told Me": Creating Big Books}

Drawing on what the children shared during the interviews, I created what could be described as an alternative textbook, in this case a big book with the children's stories. The themes covered actions and places from the children's everyday life at home and in school, and shared experiences of places like the library, the swimming hall and the football pitch in Fairfield. The 11 languages spoken by the children were represented and collected on the center pages of the book. The content relates to some places and spaces in Fairfield as well as the children's various linguistic backgrounds, but not to religion or ethnicity.

Reading the story aloud created an obvious fascination. The children were curious about the photographs of a schoolyard that illustrated some of the pages, and asked when I had taken them and whether it was from their schoolyard or not, which it was. Arriving at the center pages, we paused and chanted and clapped out the names of every language repeatedly and rhythmically. During this lesson, the children told me about the Fairfield festival, a yearly event that was going to take place the next weekend, something about which we made another book showing their other possible experiences of Fairfield as a place.

\section{Fairfield Festival: Children Writing and Drawing About Their Life}

After telling me about their experiences of the festival, which all but one student had attended, the teacher and I encouraged the children to close their eyes and think about one situation at the festival. The children were then urged to draw this situation, something that they did with great energy. This caused anxiety among some of them, and comments such as "I cannot draw" or "Can you help me draw this?" were heard from some of the children. In the next lesson, the teacher and I 
paused the activity for a while, and then with the students, we looked at the illustrated drawings of the picture book Doris runs away (Lindenbaum 2015). While looking at the illustrations, we wanted to show how the artist, Pija Lindenbaum, has chosen not to draw her pictures in a totally realistic way, and that the children's drawings, like hers, are interpretations. Over a series of lessons, the children drew and wrote about the Fairfield festival. They wrote, on their own or with help from us, what they wanted to say about their chosen situation from the festival. Eventually the book was put together and, sitting on the floor in a circle, every child got the opportunity to talk about his or her page. This was done during half of each class, and the drawings scaffolded the children's oral communication when they were explaining, reasoning and answering questions about their experiences of Fairfield festival, as illustrated in Fig. 1, where a girl reports that she won Marabou chocolate.

\section{Discussion}

The findings reported illustrate that in order to include sustainability within early literacy education, as in this first-grade classroom in Fairfield, the space of learning needs to be widened. Widening the space for teaching and learning allows opportunities for children to describe, compare and explore the content of texts and places in their neighborhood and to relate it to both the surrounding world and issues of sustainability. On the whole, the results indicate the crucial need for designing rich learning tasks that take place over several lessons, where children can participate and communicate fully with their various resources.

\section{Positive Discourses in Fairfield: Children's Reports}

The ethnographical fieldwork reveals some positive and powerful discourses in Fairfield. From the children's own words, they think highly of Fairfield. This creates possibilities for authentic literacy work involving, for example, creating short movies, which could draw on excerpts from the jointly created book. Likewise, the children could take photographs of their much-appreciated schoolyard and continue meaningful literacy work with maximum cognitive engagement, and with possibilities for maximum identity investment (Cummins 2001). If the children work in pairs with such learning tasks, this would create more opportunities for active language use, where the content is made comprehensible and where students move from everyday to subject-specific language.

As noted, many of the children talk in detail about the playgrounds between the inner courtyards. This and other information could, for example, be included in a letter to be sent to the administrator of the housing estates of Fairfield. In these and other ways, the children's thoughts and everyday experiences of Fairfield could be made public and sent out to the rest of the community, including decision makers. When children are encouraged, and given the time to describe their own world, this can result in them thinking, speculating and questioning more. Through such a carefully designed process, children can over time achieve critical literacy. Just like 
Fig. 1 Winning the lottery at Fairfield festival

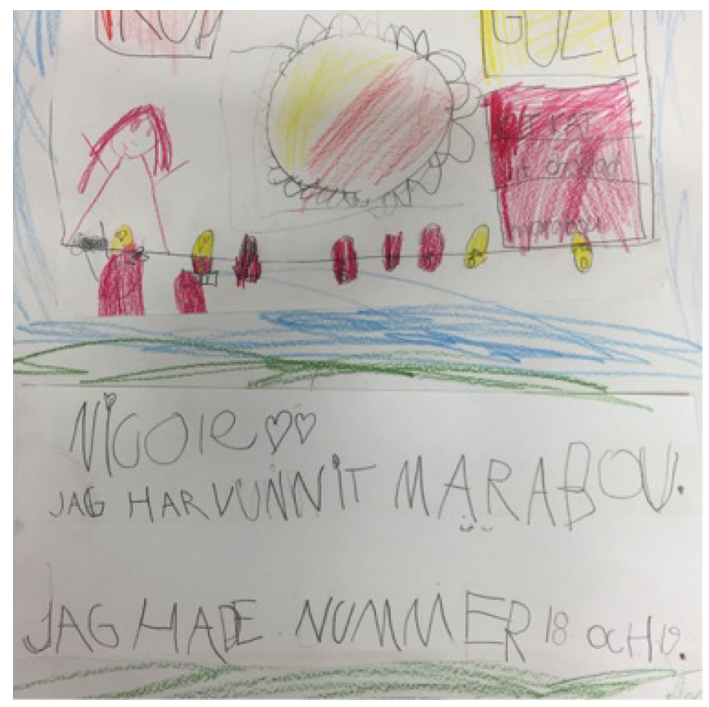

the children in the educational program for local wetlands in Australia, the children of Fairfield can take photographs, make audio-recordings and in this way have access to powerful literacy discourses that are linked to their surrounding world.

Using a textbook reader in early literacy education is common in Sweden, and the self-evident purpose is to teach children to read. As is the case with all texts, the reader cannot be said to be neutral. The reader used in this case does not in almost any sense relate to aspects of religion or ethnicity or different language backgrounds, or reflect neighborhoods like Fairfield, showing the place and the people who live there together. When planning and making choices regarding what texts to include in early literacy education, issues of recognition and possible connections to the people living in the community are of importance. This does not have to mean that a textbook reader is not bought and used in the education, but it has to be combined with a wide range of other texts, including the texts that the children produce themselves collaboratively and individually.

\section{Places as Possibilities and Place-Based Pedagogy}

Drawing on Fairfield as a place provides many spots and spaces to include in the teaching and learning of literacy, like playgrounds, the schoolyard, the shops, the church, the library and the mosque. Other possible places are the allotments, organized and taken care of by many of the older inhabitants in Fairfield with specific knowledge of sustainable cultivation. Close to Fairfield, there is a forest with a variety of trees and plant species. Likewise, the story of Fairfield includes the stories of all the people arriving in Fairfield from faraway or nearby, and their memories and life trajectories. When looking at Fairfield as a place, this involves the community as a whole. Relating the school to the surrounding community also means that possible partners of cooperation that may be already known but may not 
be necessarily used or valued, such as the local library or the second-hand shop for clothes, can be identified.

If the aim is to link literacy learning to place and sustainability, it is vital that subjects or particular skills are not taught in isolation. The focus on meaning has to be in interplay with the focus on language and the focus on use (Cummins 2001). A shared context for a certain theme, project or place, I would argue, provides opportunities to integrate issues of sustainability. When designing such learning contexts, it is possible from a Swedish perspective to balance core content and knowledge requirements with the fundamental values of democracy and participation described in the curriculum. Shared contexts within education offer opportunities for active language use and facilitate the design of rich learning tasks as well as the possibility of adapting the teaching and learning to individual children. Thinking and discussing this in collaborative ways with colleagues is, I argue, what the complex and challenging commitment of the teacher's profession looks like. When designing teaching that draws upon children's possibilities of participation and agency as well as specific knowledge aspects of curricula, it is vital to include coding, functional use, meaning-making and the critique of texts (Luke and Freebody 1997). Taken as a whole, this implies that teachers in the preschool class and grade 1 must both welcome and value the resources that students supply, while offering them new literacy resources.

\section{Setting High and Realistic Expectations for Children's Learning}

The multilingual children at Fairfield bring powerful resources to the classroom. It is of crucial importance to recognize and value these resources within education so that society can avoid having low expectations for these children's literacy. Being multilingual, like the majority of the children at Fairfield School, involves a heterogeneous and pluralistic belonging. It is not always possible to explicitly distinguish between the categories of first and second language, and these categories do not mean the same thing for all children. Behind a label such as "bilingual children," differing linguistic experiences and uses of languages may be found. The first-grade classroom in Fairfield displays this wide spectrum of linguistic variation. This also relates to the fact that these children now, and in the future, will encounter a vast amount of information drawing on a various forms of media in various subjects, which they need to sift, interpret and create knowledge from as well as to critically review. For this reason, high expectations for children's literacy and the avoidance of deficit discourses within early childhood education are crucial.

The importance of holding high expectations also implies that teachers need to accept that children's may have different starting points in their literacy and what they are capable of at any point in time. It is children's individual and varied resources that they need to be understood in order for their needs to be met. It is from different starting points that high expectations should be drawn. Children are capable of exploring sounds and letters on different levels, in different ways and drawing on different languages. Collaboration between first-language instruction and the classroom literacy work could be developed that would provide perhaps the strongest incentive for sustainable literacy. Such collaboration could provide 
children with powerful resources for communicating orally and through reading and writing in at least two languages. It is significant that although these children are part of a multilingual school, their linguistic resources are in a way taken for granted, and hence not made visible and valued. When planning and developing early literacy education it is crucial to incorporate multilingual considerations as much as possible.

\section{Conclusions and Implications}

Each school and its community form the arena in which pedagogical practices play out. In order to imagine alternatives for and new ways to support children's learning and development of literacy in relation to sustainability, I believe systematic inquiry into contextualized practice, as well as collaborative research projects with teachers, children and the rest of the community are fundamental. Development of contextualized practices should be seen as a long-term work, where the fundamental approach must be to bring forward children's own linguistic, semiotic, narrative and other communicative resources and experiences of place.

A second fundamental issue is that processes of negotiation do not, per se, result in a common and shared understanding of the complex dilemmas in supporting multilingual literacy. Negotiations might instead result in different standpoints and solutions being brought forward in transparent and democratic ways. The focus on negotiating in this research draws heavily on the crucial need to involve children to actively use language in authentic, meaningful and critical ways. At the same time, the question of negotiation perhaps tackles the most important and difficult issue of sustainability, namely how people in a community can live together while having different values, beliefs and dreams. In every community and within every group of children, there exist certain differences. At the same time, I argue in line with Appiah (2007) that there are some values that must be considered universal, like those articulated in the UN Convention on the Rights of the Child (United Nations 1989) Correspondingly, and through processes of negotiation, there are particular differences that it might be crucial to maintain and not neglect.

Future long-term and collaborative research projects with teachers and children in early childhood education need to balance the approaches described in this paper. A new approach requires using children's own powerful resources, and at the same time being aware of the double intentions of negotiating new approaches in order to link democratic values to issues of sustainability within education. Furthermore, how literacy assessment can be carried out, or not, in the early school years is a crucial one for future research. The latter is important since teachers need to focus their time and effort on children's relational writing and reading, drawing on various texts and media forms, and on collaborative learning about place and sustainability. Bringing aspects of place and sustainability might result in a deepened and more efficient literacy education, where both basic functional literacy and critical literacy are achieved. 
Acknowledgements This research was supported by the Department of Pedagogical, Curricular and Professional Studies at Gothenburg University. I thank the teacher and students who participated in this study.

Open Access This article is distributed under the terms of the Creative Commons Attribution 4.0 International License (http://creativecommons.org/licenses/by/4.0/), which permits unrestricted use, distribution, and reproduction in any medium, provided you give appropriate credit to the original author(s) and the source, provide a link to the Creative Commons license, and indicate if changes were made.

\section{References}

Alexander, R. (2008). Essays on pedagogy. New York: Routledge.

Appiah, K. A. (2007). Cosmopolitanism: Ethics in a world of strangers. London: Penguin.

Apple, M. W. (2010). Global crises, social justice, and education. New York: Routledge.

Comber, B. (2016). Literacy, place, and pedagogy of possibility. New York: Routledge.

Comber, B., \& Nixon, H. (2004). Children reread and rewrite their local neighborhoods: Critical literacies and identity work. In J. Evans (Ed.), Literacy moves on. Using popular culture, new technologies and critical literacy in the primary classroom (pp. 127-148). New York: David Fulton Publishers.

Cummins, J. (2001). Negotiating identities: Education for empowerment in a diverse society (2nd ed.). Los Angeles: California Association for Bilingual Education.

Danielsson, K., \& Selander, S. (2016). Reading multimodal texts for learning-A model for cultivating multimodal literacy. Designs for Learning, 8(1), 25-36.

Freire, P. (1970). Pedagogy of the oppressed. London: Penguin.

Gee, J. P. (1996). Social linguistics and literacies: Ideology in discourses. New York: Routledge.

Hägglund, S., \& Samuelsson, I. P. (2009). Early childhood education and learning for sustainable development and citizenship. International Journal of Early Childhood, 41(2), 49-63.

Hammersley, M., \& Atkinson, P. (1989). Ethnography. Principles in practice. London: Routledge.

Kress, G. (1997). Before writing. Rethinking the paths of literacy. London: Routledge.

Lindenbaum, P. (2015). Doris drar [Doris runs away]. Stockholm: Lilla Piratförlaget.

Lourenco, M., \& Andrade, I. A. (2013). Promoting phonological awareness in pre-primary education: Possibilities for the 'awakening to languages' approach. Language Awareness, 23(4), 304-318.

Luke, A., \& Freebody, P. (1997). The social practices of reading. In S. Muspratt, A. Luke, \& P. Freebody (Eds.), Constructing critical literacies: Teaching and learning textual practices (pp. 195-225). Cresskill, NJ: Hampton Press.

Massey, D. (2005). For space. Los Angeles: SAGE.

National Agency of Education. (2011). Curriculum for the compulsory school, preschool class and the leisure-time centre (Revised ed.). Stockholm: National Agency of Education.

Nussbaum, M. (2010). Not for profit. Why democracy needs the humanities. Princeton, NJ: Princeton University Press.

Sommerville, M. (2011a). Body/place journal writing. In M. Sommerville, B. Davies, K. Power, S. Gannon, \& P. de Carteret (Eds.), Place, pedagogy, change (pp. 13-28). Rotterdam: Sense Publishers.

Sommerville, M. (2011b). Becoming-frog: Learning place. In M. Sommerville, B. Davies, K. Power, S. Gannon, \& P. de Carteret (Eds.), Place, pedagogy, change (pp. 65-80). Rotterdam: Sense Publishers.

Sommerville, M., \& Williams, C. (2015). Sustainability education in early childhood: An updated review of research in the field. Contemporary Issues in Early Childhood, 16(2), 102-117.

Swedish Research Council. (2002). Forskningsetiska Principer [Ethical Principles for Research]. Stockholm: Swedish Research Council.

UNESCO. (2005). UN Decade of Education for Sustainable Development 2005-2014: The DESD at a glance. Paris. Author. Retrieved from http://unesdoc.unesco.org/images/0014/001416/141629e.pdf.

United Nations. (1989). Convention on the Rights of the Child. General Assembly resolution 44/25, 20 Nov. 1989. U.N. Doc. A/RES/44/25. New York. Author. Retrieved from http://www.ohchr.org/EN/ ProfessionalInterest/Pages/CRC.aspx. 
Vasquez, V. (2001). Constructing a critical curriculum with young children. In B. Comber \& A. Simpson (Eds.), Negotiating critical literacies in classrooms (pp. 55-66). Marwah, NJ: Lawrence Erlbaum. Wänblad, M. (2011). Den magiska kulan [The Magic Marble]. Stockholm: Natur \& Kultur.

Whyte, S. R. (1999). Ethnographic fieldwork. A pragmatic perspective. Nordisk Pedagogik, 19(4), 235-244. 